\title{
Induced resistance to common rust (Puccinia sorghi), in maize (Zea mays)
}

\author{
Carmen Alicia Zúñiga-Silvestre ${ }^{1}$, Carlos De-León-García-de-Alba ${ }^{1 *}$, Victoria Ayala-Escobar ${ }^{1}$, \\ Víctor A. González-Hernández²
}

${ }^{1}$ Instituto de Fitosanidad, Colegio de Postgraduados, Carretera México-Texcoco Km 36.5, Montecillo, Texcoco, Estado de México, C.P. 56230, México, ${ }^{2}$ Instituto de Fisiología Vegetal, Colegio de Postgraduados, Carretera México-Texcoco Km 36.5, Montecillo, Texcoco, Estado de México, C.P. 56230, México

\section{A B S T R A C T}

The common rust of maize (Zea mays L.), caused by Puccinia sorghi Schw., develops pustules on the leaves of maize plants, reducing the leaf area and production of the photoassimilates necessary for grain filling. The host possesses genes coding for different proteins related to the defense mechanisms that prevent the establishment of the pathogen. However, there are susceptible plants that are unable of preventing pathogen attack. This condition depend on biotic and abiotic factors known as inducers of resistance which are able of activating the physico-chemical or morphological defense processes to counteract the invasion of the pathogen. The Ceres XR21 maize hybrid is susceptible to $P$. sorghi. In this work, maize hybrid was evaluated under a split-split- plot design established in two spring-autumn cycles in the years 2016 and 2017, in which five commercial products of biological and chemical origin reported as inducers of resistance, plus a fungicide were compared. The results showed that trifloxystrobin + tebuconazole (Consist Max ${ }^{\circ}$, sprayed on the foliage with $1.5 \mathrm{X}$ the commercially recommended dose, showed significant better response in most evaluated variables, because it controlled better the pathogen $P$. sorghi and maize plants increased grain yield.

Keywords: Zea mays L; Phytopathogen; Resistance inducer; Defense mechanism; Photosynthesis

\section{INTRODUCTION}

Maize (Zea mays L.) along with wheat (Triticum aestivum L.) and rice (Oryza sativa L.), are the primary staple food cereals in many countries. In addition, maize is used in industry for the production of starch, oil, sweeteners, dextrins, ethanol, paper, antibiotics, cosmetics, and compounds that can replace the function of petroleum and its derivatives (Grande y Orozco, 2013). In Mexico, maize is affected by pests and diseases which reduce grain yield and quality, causing losses of $34.8 \%$ in production (INIFAP, 2015). This crop is affected by three rusts caused by polysora rust (Puccinia polysora Underw.), tropical rust (Physopella reae (Mains) Cummins \& Ramachar), and common rust (Puccinia sorghi Schwein), which develop pustules on the leaves particularly at flowering time, or a little later. Their easy adaptations allow the rusts to have a wide distribution in subtropical and temperate climates and in highlands with high humidity (Programa de Maíz, 2004). The infection caused by $P$. sorghi induces decreases in the photosynthetic leaf area and damages the epidermis of the host, thus affecting different physiological processes which reduce the amount of photoassimilates and decreases grain production (González, 2005).

The resistance inducers are exogenous molecules capable of stimulating plants for activating their defense mechanisms to protect themselves from phytopathogenic aggressions (Gómez and Reis, 2011). Inducers of biological or chemical origin, combined with good agronomic practices, may be successful in protecting crops during the growing season. Due to their origin and composition, the inducers show different effects on host development and vigor, as well as reducing the incidence and severity of diseases. The evaluation of these variables is useful to determine the effect of different inducers in the control of pests and diseases through physiological and agronomic processes in plants (Jiménez et al., 2012). Several products with fungicidal and efficient biological effect as chemical inducers have been evaluated to control diseases in

\footnotetext{
*Corresponding author:

Carlos De-León-García-de-Alba, Instituto de Fitosanidad, Colegio de Postgraduados, Carretera México-Texcoco Km 36.5, Montecillo, Texcoco, Estado de México, C.P. 56230. México. E-mail: cdeleon@colpos.mx
}

Received: 29 October 2019; $\quad$ Accepted: 31 December 2019 
horticultural crops of the Solanaceae family. In grasses, the potential of chemical inducers in controlling diseases has not been proved. Based on these interesting possibilities, in the present research six commercial products were evaluated as inducers of resistance to $P$. sorghi in maize plants grown under field conditions.

\section{MATERIALS AND METHODS}

Field experiments were conducted in the years 2016 and 2017 at the Experimental Station of the Colegio de Postgraduados, Campus Montecillo (19 $29^{\circ}$ ' 4.26” N and $98^{\circ} 53^{\prime} 42.18^{\prime \prime} \mathrm{W}$, at an altitude of $2250 \mathrm{~m}$ ). The climate is classified as $\mathrm{Cb}\left(\mathrm{w}_{\mathrm{p}}\right)(\mathrm{w})(\mathrm{i})$ ), corresponding to a temperate subhumid with oscillation between 5 and $7{ }^{\circ} \mathrm{C}$, with summer rains (García, 1988). In the two growing seasons plantings were done in April 4, 2016 and April 6, 2017, both with seeds of the commercial hybrid maize Ceres XR21, reported as susceptible to $P$. sorghi. The entire experiment included 126 plots of $7.2 \mathrm{~m}^{2}$ each, with 2 rows $3 \mathrm{~m}$ long, $0.80 \mathrm{~m}$ between rows, 22 plants per plot, and $0.16 \mathrm{~m}$ between plants, with an average density of 80,000 plants ha ${ }^{-1}$. The practices of crop management were carried out in accordance with the Experiment Station. After planting, four irrigations were applied by gravity, until the rains were established in the Summer. The soil was fertilized with a dose of 160-60-00 kg NPK ha-1, respectively. Cultivation was done with a tractor 20 days after plants emerged. Weeds were controlled manually, and there was no need to control diseases, except for the treatments applied to evaluate the common rust severity.

The strategy to measure the effect of common rust caused by $P$. sorghi, consisted of three points: 1 ) apply five products reported as inducers of resistance, and a fungicide; 2) from the recommended commercial dose, two additional doses were included to determine if they were able to overcome the efficiency of the commercial; and 3) compare the efficiency of the products when applied to the soil or sprayed on the foliage. For this, an experimental split-split plot design was implemented, with three replications, where the main plots represent the six products: the fungicide trifloxystrobin + tebuconazole $\left(\right.$ Consist $\operatorname{Max}^{\circledR}$ ), plus five products reported as inducers of resistance, including Bacillus subtillis (Serenade Max ${ }^{\circledR}$ ), Bacillus firmus + clothianidin $\left(\right.$ Poncho Votivo ${ }^{\circledR}$ ), Fosetil aluminum $\left(\right.$ Alliete $\left.^{\circledR}\right)$, harpin protein Ea (Messenger ${ }^{\circledR}$ ), Acibenzolar $\mathrm{S}$ methyl (Actigard $50 \mathrm{GS}^{\circledR}$ ), and a control (water). The subplots corresponded to the two methods of treatment application: to the soil at the planting time, and spraying at V6-V7 stage when young plants were 20 days-old after seedling emergence (Ritchie et al., 1986). Sub-subplots involved the three doses per treatment: half $(50 \%)$ of the recommended dose, the recommended dose $(100 \%)$, and 1.5 times $(150 \%)$ the recommended dose (Table 1$)$.

To determine the effect of treatments on induction of resistance to Puccinia sorghi in maize plants, the following agronomic parameters were measured:

1) Disease severity. It was recorded at the beginning of infection, in August in the two cycles 2016 and 2017, along five sampling dates separated by an interval of 15 days, using an arbitrary scale of 1 to 5 levels of damage (Table 2). 2) Anthesis-silking interval (ASI), as the difference of days to $50 \%$ silking minus days to $50 \%$ anthesis. 3) Plant and ear heights, measured from the stem crown level to the base of the ear and tassel, respectively. 4) Plant and ear aspects, using a scale $1-5$, where $1=\operatorname{very} \operatorname{good}(100 \%), 2=\operatorname{good}$ $(90 \%), 3=$ fair $(80 \%), 4=\operatorname{bad}(70 \%), 5=$ very poor (60-0 \%). 5) Percent of healthy and rotten ears. 6) Grain yield, in $t \mathrm{ha}^{-1}$; harvest was done at the grain physiological maturity, considering the appearance of the black layer at the kernel bottom. The kernel moisture content was measured in each treatment using a Mini GAC Plus moisture tester (Dickey John, USA), and then kernel moisture was standardized to $15 \%$. The procedures and measurement units used in the

Table 1: Treatments applied to the maize crop for controlling Puccinia sorghi

\begin{tabular}{|c|c|c|c|c|}
\hline \multirow[t]{2}{*}{ Main plot } & \multirow[t]{2}{*}{ Subplot } & \multicolumn{3}{|c|}{ Sub-subplot } \\
\hline & & $50 \%$ & Commercial (100\%) & $150 \%$ \\
\hline $\begin{array}{l}\text { Actigard } 50 \mathrm{GS}^{\circledR} \\
\text { (Acibenzolar metil) }\end{array}$ & $\begin{array}{l}\text { Soil (at sowing) } \\
\text { Foliar spray (V7) }\end{array}$ & $20 \mathrm{~g} / \mathrm{ha}$ & $40 \mathrm{~g} / \mathrm{ha}$ & $60 \mathrm{~g} / \mathrm{ha}$ \\
\hline $\begin{array}{l}\text { Alliete }^{\circledR} \\
\text { (Fosetyl aluminum) }\end{array}$ & $\begin{array}{l}\text { Soil (at sowing) } \\
\text { Foliar spray (V7) }\end{array}$ & $1.25 \mathrm{~kg} / \mathrm{ha}$ & $2.5 \mathrm{~kg} / \mathrm{ha}$ & $3.75 \mathrm{~kg} / \mathrm{ha}$ \\
\hline $\begin{array}{l}\text { Consist Max } \\
\text { (trifloxystrobin+tebuconazol) }\end{array}$ & $\begin{array}{l}\text { Soil (at sowing) } \\
\text { Foliar spray (V7) }\end{array}$ & $0.15 \mathrm{~L} / \mathrm{ha}$ & $0.30 \mathrm{~L} / \mathrm{ha}$ & $0.45 \mathrm{~L} / \mathrm{ha}$ \\
\hline $\begin{array}{l}\text { Messenger } \\
\text { (harpin protein Ea) }\end{array}$ & $\begin{array}{l}\text { Soil (at sowing) } \\
\text { Foliar spray (V7) }\end{array}$ & $125 \mathrm{~g} / \mathrm{ha}$ & $250 \mathrm{~g} / \mathrm{ha}$ & $375 \mathrm{~g} / \mathrm{ha}$ \\
\hline $\begin{array}{l}\text { Poncho Votivo } \\
\text { (Bacillus firmus+clothianidin) }\end{array}$ & $\begin{array}{l}\text { Soil (at sowing) } \\
\text { Foliar spray (V7) }\end{array}$ & $40 \mathrm{~mL} / 80,000$ seeds & $80 \mathrm{~mL} / 80,000$ seeds & $100 \mathrm{~mL} / 80,000$ seeds \\
\hline $\begin{array}{l}\text { Serenade Max } \\
\text { (Bacillus subtillis) }\end{array}$ & $\begin{array}{l}\text { Soil (at sowing) } \\
\text { Foliar spray (V7) }\end{array}$ & $1.5 \mathrm{~kg} / \mathrm{ha}$ & $3 \mathrm{~kg} / \mathrm{ha}$ & $4.5 \mathrm{~kg} / \mathrm{ha}$ \\
\hline
\end{tabular}


Table 2: Evaluation scale for Puccinia sorghi rust

\begin{tabular}{llc}
\hline Scale & Severity & Leaf area with pustules \\
\hline 1 & Resistant & $10 \%$ \\
2 & Moderately resistant & $20-30 \%$ \\
3 & Moderately Susceptible & $40-50 \%$ \\
4 & Susceptible & $60-70 \%$ \\
5 & Very susceptible & $100 \%$ \\
\hline
\end{tabular}

data record are described in IBPGR (1991), Edmeades et al. (1996), and Angeles et al. (2010).

Regarding physiological variables, the following were evaluated:

1) Total chlorophyll (SPAD units): measured with a SPAD 502 instrument (Minolta Ltd., Japan). Sixty days after planting, chlorophyll readings were initiated and thereafter every 15 days. In each plot, three readings were recorded in the middle of the ear-leaf of three plants, all within an 11 and $13 \mathrm{~h}$ time period; the average of such readings was recorded for statistical analysis. 2) Net rate of photosynthesis $\left(\mathrm{An} ; \mu \mathrm{mol} \mathrm{CO} \mathrm{Cm}^{-2} \mathrm{~s}^{-1}\right.$ ): in each plot, one ear-leaf in three plants was selected with the same criteria as for measuring chlorophyll. Measurements were done with a portable apparatus LI-COR 6400 (LICOR, Inc. USA) operating in open mode to allow the air circulation with a controlled atmosphere around the measured leaf fraction for approximately $1 \mathrm{~min}$, keeping the $\mathrm{CO}_{2}$ level of incoming air constant and taking the reading when the coefficient of variation was $\leq 2 \%$.

The measurement of the three experimental replicates required two days. The first and second replication of the experiment was taken on the first day, and the third replication was measured on the third day. During the readings, the photosynthetic photon flux was at a minimum of 1000 to $1200 \mu \mathrm{mol}$ photons $\mathrm{m}^{-2} \mathrm{~s}^{-1}$, and air flow was adjusted to $400-408 \mu \mathrm{mol} \mathrm{mol}^{-1}$. The photosynthetic readings were made in stages V10, VT, and R5 (10 mature leaves, tasseling, and dent kernels, respectively) which are detailed by Ritchie et al. (1986) for maize development, based on the scale of Hanway (1966). The procedure and units used were described by Rincón and Ligarreto (2010), and Sandoval et al. (2010).

For the statistical analysis of variables measured in several periods of time on the same experimental unit, three options were used: univariate analyzes with the RANDOM instruction of the GLM, univariate or multivariate analysis through linear transformations using the REPEATED instruction of the GLM, and mixed models of covariance with the MIXED procedure (González et al., 2007).

The separation of means was done by GLM Fisher DMS test $(\mathrm{p} \leq 0.05)$ using the SAS 9.4 package.

\section{RESULTS AND DISCUSSION}

\section{Severity}

Even though results obtained showed a low severity of common rust, in the two years of evaluation it was observed that in the measured samples from the five treatments, Consist Max $^{\circledR}$ (trifloxystrobin (strobilurins) + tebuconazole) provided greater protection to maize plants against $P$. sorghi, significantly decreasing $(\alpha=0.05)$ the severity of the pathogen. Regarding the application method, from the third sampling the spray at V7 ( $7^{\text {th }}$ mature leaf) had a greater significant effect in controlling the disease, compared to the soil application. No significant differences were detected between dosages (Table 3).

Similar results were reported by Shah and Dillar (2010) who controlled P. sorghi in sweet corn hybrids, applying strobilurins in levels of 1,10 , and $20 \%$ with only one foliar application. According to Rodríguez et al. (2015), preventive application is convenient after applying strobilurins to three maize hybrids at two stages: V10 $\left(10^{\text {th }}\right.$ mature leaf) and R1 (silking stage), resulting in less severity when applying the product at the V10 phenologic stage. Carmona et al. (2009) sprayed maize plants with trifloxystrobin + tebuconazole with three doses (half the recommended dose, recommended dose, and twice the recommended dose), at different times of application; they found significantly lower severity of $P$. sorghi in plants treated with all doses compared to the control, concluding that for efficient control of the disease, applications should be done when plants show $1 \%$ severity in the flag leaf.

The other resistance inducers studied in the present work, including Bacillus subtillis (Serenade Max ${ }^{\circledR}$ ), Bacillus firmus + clotianidin (Poncho Votivo ${ }^{\circledR}$ ), Fosetil aluminum (Alliete ${ }^{\circledR}$ ), Harpin Ea protein $\left(\right.$ Messenger ${ }^{\mathbb{B}}$ ), and acibenzolar S methyl (Actigard $50 \mathrm{GS}^{\circledR}$ ), also induced resistance, though to a lesser degree than Consist $\mathrm{Max}^{\circledR}$, all of them exceeding the absolute control which showed the highest severity of damage from the third sampling date (Table 3).

\section{Disease progress}

In the mean comparison test ( $\mathrm{p} \leq 0.05)$, plants treated with Consist $\mathrm{Max}^{\circledR}$ showed significantly lower rust severity by P. sorghi than the control plants (Table 3). Thus, a nonlinear regression analysis was performed with the statistical package CurveExpert 1.4, to associate the pathogen growth as a function of time. The degree of severity over time adjusted best to polynomial models (Table 4), and the growth of severity in the control showed the greatest increase over time than plants treated with Consist $\operatorname{Max}^{\circledR}$ (trifloxystronin + tebuconazole). 
Table 3: Severity of Puccinia sorghi in maize plants submitted to treatments, methods of application, and doses. Mean values calculated from two growing seasons ${ }^{\S}$

\begin{tabular}{|c|c|c|c|c|c|}
\hline & \multicolumn{5}{|c|}{ Severity of Puccinia sorghi } \\
\hline & Sampling 1 & Sampling 2 & Sampling 3 & Sampling 4 & Sampling 5 \\
\hline \multicolumn{6}{|l|}{ Main plot } \\
\hline Consist Max ${ }^{\circledR}$ & $0.8^{\mathrm{a}}$ & $1.2^{\mathrm{a}}$ & $1.4^{\mathrm{a}}$ & $1.8^{\mathrm{a}}$ & $2.1^{\mathrm{a}}$ \\
\hline Serenade Max $^{\circledR}$ & $1.3^{\mathrm{b}}$ & $1.8^{\mathrm{b}}$ & $1.6^{\mathrm{a}}$ & $2.0^{\mathrm{bc}}$ & $2.4^{b}$ \\
\hline Actigard $^{\circledR}$ & $1.0^{\mathrm{ab}}$ & $1.4^{\mathrm{ab}}$ & $1.5^{\mathrm{a}}$ & $2.0^{\mathrm{ab}}$ & $2.3^{b}$ \\
\hline Alliete ${ }^{\circledR}$ & $1.0^{\mathrm{ab}}$ & $1.3^{\mathrm{ab}}$ & $1.5^{\mathrm{a}}$ & $2.0^{\mathrm{ab}}$ & $2.3^{b}$ \\
\hline Poncho Votivo ${ }^{\circledR}$ & $1.0^{\mathrm{ab}}$ & $1.4^{\mathrm{ab}}$ & $1.6^{\mathrm{ab}}$ & $2.0^{\mathrm{abc}}$ & $2.4^{b}$ \\
\hline Messenger $r^{\circledR}$ & $1.0^{\mathrm{ab}}$ & $1.3^{\mathrm{ab}}$ & $1.6^{\mathrm{a}}$ & $2.0^{\mathrm{ab}}$ & $2.4^{b}$ \\
\hline Control & $1.0^{\mathrm{ab}}$ & $1.4^{\mathrm{ab}}$ & $1.8^{b}$ & $2.2^{\mathrm{c}}$ & $3.0^{c}$ \\
\hline Average & 0.7 & 1.4 & 1.5 & 1.9 & 2.37 \\
\hline LSD (0.05) & 0.2 & 0.4 & 0.2 & 0.2 & 0.17 \\
\hline CV $(\%)$ & 22.3 & 47 & 11.3 & 11.1 & 8.02 \\
\hline $\mathrm{R}^{2}$ & 0.7 & 0.6 & 0.7 & 0.7 & 0.8 \\
\hline \multicolumn{6}{|l|}{ Sub plot } \\
\hline Application spray & $1.0^{\mathrm{a}}$ & $1.4^{\mathrm{a}}$ & $1.5^{\mathrm{a}}$ & $1.9^{a}$ & $2.3^{a}$ \\
\hline Application in soil & $1.0^{\mathrm{a}}$ & $1.4^{\mathrm{a}}$ & $1.6^{b}$ & $2.0^{b}$ & $2.5^{b}$ \\
\hline LSD (0.05) & 0.1 & 0.3 & 0.1 & 0.1 & 0.2 \\
\hline \multicolumn{6}{|l|}{ Sub subplot } \\
\hline Dose $50 \%$ & $1.0^{\mathrm{a}}$ & $1.3^{\mathrm{a}}$ & $1.6^{\mathrm{a}}$ & $2.0^{\mathrm{a}}$ & $2.4^{a}$ \\
\hline Dose $100 \%$ & $1.0^{\mathrm{a}}$ & $1.5^{\mathrm{a}}$ & $1.5^{\mathrm{a}}$ & $2.0^{\mathrm{a}}$ & $2.4^{\mathrm{a}}$ \\
\hline Dose $200 \%$ & $1.0^{\mathrm{a}}$ & $1.3^{\mathrm{a}}$ & $1.6^{\mathrm{a}}$ & $2.0^{\mathrm{a}}$ & $2.4^{a}$ \\
\hline LSD (0.05) & 0.1 & 0.3 & 0.1 & 0.1 & 0.1 \\
\hline
\end{tabular}

sValues followed by the same letter within the same column do not differ statistically from each other (Tukey $\leq 0.05$ ).

Table 4: A model to simulate the severity level of $P$. sorghi in maize plants, as a function of time (days)

\begin{tabular}{|c|c|c|}
\hline \multirow[t]{2}{*}{ Polynomial model } & \multicolumn{2}{|c|}{ Function $y=a+b x+c x^{\wedge} 2+d x^{\wedge} 3$} \\
\hline & Control & Consist Max ${ }^{\circledR}$ \\
\hline \multirow[t]{4}{*}{ Coefficients } & $a=1.0088036117$ & $a=0.791948833$ \\
\hline & $b=0.0056437588$ & $b=0.024686666$ \\
\hline & $C=0.0008328177$ & $c=-0.00033734$ \\
\hline & $d=-0.000006983$ & $d=0.000004241$ \\
\hline Correlation coefficient & 0.8979 & 0.7163 \\
\hline Standard error & 0.3377 & 0.4077 \\
\hline
\end{tabular}

\section{Plant height index}

The stalk accumulates the nutrients elaborated in the process of photosynthesis and then they are transferred to the ear for grain filling. With the plant and ear height data, the height index = ear height/plant height is calculated, where the value 0.5 is expected as the desirable point of insertion of the ear, determining the tolerance to lodging. Our results showed no significant differences among treatments, whose values varied from 0.44 to 0.46 (Table 5), an acceptable range indicating enough stem strength to avoid lodging by wind. According to Reynoso et al. (2014), values of 0.4 - 0.5 guaranteed lower probability of root and stem lodging of 17 hybrids evaluated in different zones of central Mexico. Hongguang et al. (2012) found that height is associated by QTLs, suggesting that it is important to measure the plant and ear height as there is a close relationship conditioning stalk resistance to lodging, canopy photosynthesis and grain yield. In addition, the plant and ear height are not only determined genetically, but are also regulated by environmental conditions including the application of products such as fertilizers. Palafox et al. (2016) mention that breeding programs should look for genotypes with an ear and plant height relationship $\leq 0.5$, as values higher than this may result in stem lodging problems, as they have the ear position above half of the plant height.

\section{Flowering interval (anthesis-silking interval) (ASI)}

Serenade Max $^{\circledR}$ showed lower ASI than Messenger ${ }^{\circledR}$ and control treatments with significant difference $(\alpha=0.05)$, with a flowering interval of 1.77 days (Table 5) vs. 2.16 and 2.22 days. The other treatments showed intermediate ASI values.

The flowering interval values indicate that silking occurred some days after pollen shedding, which ensures the stigma pollination during anthesis, and the evaluated plants did not show protandry or protogyny. According to Noriega et al. (2011), the tassel should emerge before initiation of pollen release (anthesis), 1 or 2 days before the emission of stigmas. In field conditions, the greater the synchrony between tassel and silking offers a greater possibility of successful pollination. MacRoberth et al. (2015) have emphasized the importance of knowing the duration of pollen production and the emission of stigmas (7-14 days), since a lag between male and female flowering will have an impact on grain production. 
Table 5: Mean values of anthesis-silking interval (ASI), height index, plant and ear aspects and net rate of photosynthesis. Average values calculated from two growing seasons ${ }^{\S}$

\begin{tabular}{|c|c|c|c|c|c|c|c|}
\hline & \multirow[t]{2}{*}{ Interval (ASI) } & \multirow[t]{2}{*}{ Hight index } & \multirow[t]{2}{*}{ Plant aspect } & \multirow[t]{2}{*}{ Ear aspect } & \multicolumn{3}{|c|}{ Net rate of photosynthesis $\left(\mu \mathrm{mol} \mathrm{CO} \mathrm{Cm}^{-2} \mathrm{~s}^{-1}\right)$} \\
\hline & & & & & V10 & VT & R5 \\
\hline \multicolumn{8}{|l|}{ Main plot } \\
\hline Consist Max ${ }^{\circledR}$ & $1.9^{\mathrm{ab}}$ & $0.44^{\mathrm{a}}$ & $1.6^{\mathrm{ab}}$ & $1.6^{\mathrm{a}}$ & $29.0^{\mathrm{a}}$ & $30.9^{b c}$ & $23.5^{\mathrm{a}}$ \\
\hline Serenade $\mathrm{Max}^{\circledast}$ & $1.7^{\mathrm{a}}$ & $0.44^{\mathrm{a}}$ & $1.7^{\mathrm{ab}}$ & $1.8^{\mathrm{ab}}$ & $29.1^{\mathrm{a}}$ & $35.0^{\mathrm{abc}}$ & $20.5^{\mathrm{bc}}$ \\
\hline Actigard $^{\circledR}$ & $1.9^{\mathrm{ab}}$ & $0.45^{\mathrm{a}}$ & $1.6^{\mathrm{a}}$ & $1.6^{\mathrm{a}}$ & $31.9^{a}$ & $39.0^{\mathrm{a}}$ & $18.1^{c}$ \\
\hline Alliete ${ }^{\circledR}$ & $2.1^{\mathrm{ab}}$ & $0.46^{a}$ & $1.6^{\mathrm{ab}}$ & $1.7^{\mathrm{ab}}$ & $27.7^{\mathrm{a}}$ & $35.6^{\mathrm{ab}}$ & $21.3^{\mathrm{ab}}$ \\
\hline Poncho Votivo ${ }^{\circledR}$ & $2.1^{\mathrm{ab}}$ & $0.45^{\mathrm{a}}$ & $1.7^{\mathrm{ab}}$ & $1.7^{\mathrm{ab}}$ & $30.3^{a}$ & $35.8^{\mathrm{ab}}$ & $23.2^{\mathrm{a}}$ \\
\hline Messenger $^{\circledR}$ & $2.2^{\mathrm{b}}$ & $0.44^{\mathrm{a}}$ & $1.7^{\mathrm{ab}}$ & $1.8^{\mathrm{ab}}$ & $31.2^{\mathrm{a}}$ & $27.7^{c}$ & $19.2^{\mathrm{bc}}$ \\
\hline Control & $2.2^{\mathrm{b}}$ & $0.44^{a}$ & $1.9^{b}$ & $2.1^{\mathrm{b}}$ & $31.1^{\mathrm{a}}$ & $40.8^{a}$ & $23.4^{\mathrm{a}}$ \\
\hline Average & 2.0 & 0.44 & 1.7 & 1.8 & 30.2 & 34.9 & 21.3 \\
\hline LSD (0.05) & 0.4 & 0.22 & 0.3 & 0.4 & 6.1 & 7.79 & 2.5 \\
\hline CV (\%) & 25.7 & 4.6 & 16.4 & 14.7 & 22.7 & 32.7 & 11.5 \\
\hline $\mathrm{R}^{2}$ & 0.7 & 0.7 & 0.8 & 0.8 & 0.6 & 0.6 & 0.9 \\
\hline \multicolumn{8}{|l|}{ Sub plot } \\
\hline Spray & $2.0^{\mathrm{a}}$ & $0.44^{a}$ & $1.6^{\mathrm{a}}$ & $1.7^{\mathrm{a}}$ & $29.3^{a}$ & $35.2^{\mathrm{a}}$ & $20.8^{a}$ \\
\hline Soil & $2.1^{\mathrm{a}}$ & $0.45^{\mathrm{a}}$ & $1.8^{\mathrm{a}}$ & $1.9^{a}$ & $31.1^{\mathrm{a}}$ & $34.8^{a}$ & $21.8^{a}$ \\
\hline LSD (0.05) & 0.2 & 0.006 & 0.2 & 0.2 & 3.1 & 6.7 & 1.3 \\
\hline \multicolumn{8}{|l|}{ Sub subplot } \\
\hline Dose $50 \%$ & $2.0^{\mathrm{a}}$ & $0.45^{a}$ & $1.7^{\mathrm{a}}$ & $1.8^{\mathrm{a}}$ & $31.0^{\mathrm{a}}$ & $37.1^{\mathrm{a}}$ & $22.8^{a}$ \\
\hline Dose $100 \%$ & $2.0^{\mathrm{a}}$ & $0.44^{b}$ & $1.7^{\mathrm{a}}$ & $1.7^{\mathrm{a}}$ & $29.7^{a}$ & $35.7^{\mathrm{ab}}$ & $21.2^{\mathrm{a}}$ \\
\hline Dose $200 \%$ & $2.1^{\mathrm{a}}$ & $0.44^{\mathrm{ab}}$ & $1.7^{\mathrm{a}}$ & $1.8^{\mathrm{a}}$ & $29.8^{a}$ & $32.1^{b}$ & $18.5^{b}$ \\
\hline LSD (0.05) & 0.2 & 0.01 & 0.1 & 0.1 & 3.0 & 5.0 & 1.6 \\
\hline
\end{tabular}

sValues followed by the same letter within the same column do not differ statistically from each other (Tukey $\leq 0.05$ ).

\section{Plant and ear aspects}

For the variable plant aspect qualitatively assessed with a scale 1-5 (IBPGR 1991), where $1=$ very $\operatorname{good}(100 \%)$, $2=\operatorname{good}(90 \%), 3=$ fair $(80 \%), 4=\operatorname{sufficient}(70 \%)$, and $5=$ poor $(60-0 \%)$, significant differences were obtained between the products evaluated. Actigard ${ }^{\circledR}$ showed good results, followed by Alliete ${ }^{\circledR}$ and Consist Max ${ }^{\circledR}$ (Table 5), since treated plants showed a deeper green color and uniformity in plant height and vigor. In ear aspect, Actigard ${ }^{\circledR}$ and Consist Max $^{\circledR}$ significantly overrated $(\alpha=0.05)$ the control in ear aspect and uniformity in grain filling (Table 5).

\section{Net rate of photosynthesis}

In the three photosynthesis readings, the first at the V10 stage (10 mature leaves) when the plant begins a rapid, steady increase in nutrient and dry weight accumulation which continues until the reproductive (R1, silking) stages (Ritchie et al., 1986), showed no significant difference among treatments $(\alpha=0.05)$, with values ranging from 27.7 to $31.9 \mu \mathrm{mol} \mathrm{CO} \mathrm{m}^{-2} \mathrm{~s}^{-1}$. At the VT phenologic stage (tasseling), approximately 2-3 days before silk emergence, the maize plants nearly attained full height and pollen shed begins (Ritchie et al., 1986). At this stage, all plants except those treated with Messenger ${ }^{\circledR}$, increased the photosynthetic rate with significant gain over the control plants $\left(40.81 \mu \mathrm{mol} \mathrm{CO} \mathrm{m}^{-2} \mathrm{~s}^{-1}\right.$ ) and over the Actigard ${ }^{\circledR}$ treated plants $\left(39.03 \mu \mathrm{mol} \mathrm{CO}_{2} \mathrm{~m}^{-2} \mathrm{~s}^{-1}\right.$. This increase, recorded at the VT stage, is attributed to the increase of the optimal metabolism of the plant in order to produce the necessary energy for the formation of reproductive systems and the photoassimilates required for the initiation of kernel development. Among the methods of application, there were no significant differences, and among doses the lowest dose $(50 \%)$ showed a significant reduction.

In the last reading, recorded in R5 stage, at 35-42 days after silking, corresponding to kernel formation (Ritchie et al., 1986), plants treated with Consist Max, Poncho Votivo and the control, showed significant differences $(\alpha=0.05)$, with values of $23.48,23.16$ and $23.43 \mu \mathrm{mol}$ $\mathrm{CO}_{2} \mathrm{~m}^{-2} \mathrm{~s}^{-1}$, respectively, which exceeded Actigard with value of $8.09 \mu \mathrm{mol} \mathrm{CO} \mathrm{m}^{-2} \mathrm{~s}^{-1}$, though it had shown to be the best in photosynthesis in the second sample. Between methods of application, no significant differences were recorded, and between the doses, the lowest (50\%) and the commercial $(100 \%)$ showed significant differences, unlike the second VT sampling in which only the upper leaves reached maturity and their maximum photosynthetic capacity. Plants in the third sample in R5, presented a lower photosynthetic rate of approximately 23-50\% (Table 5), which may be attributed to the approach to leaf senescence.

Plants showing the lowest photosynthetic rate compared to the control could be due to an acceleration of use of energy due to effect of the treatments (Table 5). The importance of measuring the rate of photosynthesis according to Gutiérrez et al. (2005), is related to grain yield and can be 
used as a physiological parameter to predict an increase in production. These authors also mention that chlorophyll levels are not directly associated with photosynthesis, as some crops have a high photosynthetic rate even without a high chlorophyll content, more associated to the content of foliar nitrogen which does not affect the photosynthetic activity of the plant.

\section{Chlorophyll content}

Treatments did not cause significant variation in chlorophyll content, except on the first date of measurement where Actigard ${ }^{\circledR}$, Messenger ${ }^{\circledR}$ and Poncho Votivo ${ }^{\circledR}$ had higher chlorophyll contents with 53.09, 52.84 and 52.47 SPAD units (Table 6). The spray application showed significantly higher chlorophyll contents in maize plants at the last two readings, and the dose that showed the highest concentration of this pigment was the commercial dose, but only in the first reading since in the four subsequent readings there were not significant differences among treatments.

Mendoza et al. (2006) point out that chlorophyll levels change in relation to the maize genotype and to the nitrogen content in the plant, in addition to alterations

\begin{tabular}{|c|c|c|c|c|c|}
\hline & \multicolumn{5}{|c|}{$\begin{array}{l}\text { Chlorophyll content } \\
\text { (SPAD units) }\end{array}$} \\
\hline & Date 1 & Date 2 & Date 3 & Date 4 & Date 5 \\
\hline & V10 & V12 & VT & R1 & R4 \\
\hline \multicolumn{6}{|l|}{ Main plot } \\
\hline $\begin{array}{l}\text { Consist } \\
\text { Max }^{\circledR}\end{array}$ & $50.5^{b}$ & $48.3^{a}$ & $52.5^{a}$ & $47.3^{a}$ & $47.3^{a}$ \\
\hline $\begin{array}{l}\text { Serenade } \\
\text { Max }^{\circledR}\end{array}$ & $52.3^{\mathrm{ab}}$ & $50.7^{a}$ & $50.4^{a}$ & $49.5^{a}$ & $49.5^{\mathrm{a}}$ \\
\hline Actigard $^{\circledR}$ & $53.1^{a}$ & $49.1^{a}$ & $48.7^{a}$ & $47.4^{\mathrm{a}}$ & $47.4^{a}$ \\
\hline Alliete $^{\circledR}$ & $51.5^{\mathrm{ab}}$ & $49.5^{a}$ & $51.1^{\mathrm{a}}$ & $48.3^{a}$ & $48.3^{a}$ \\
\hline $\begin{array}{l}\text { Poncho } \\
\text { Votivo }^{\circledast}\end{array}$ & $52.5^{a}$ & $48.5^{\mathrm{a}}$ & $50.6^{a}$ & $49.8^{a}$ & $49.8^{a}$ \\
\hline Messenger ${ }^{\circledR}$ & $52.8^{a}$ & $47.9^{a}$ & $48.1^{\mathrm{a}}$ & $49.5^{a}$ & $49.5^{\mathrm{a}}$ \\
\hline Control & $52.4^{\mathrm{ab}}$ & $49.7^{a}$ & $51.2^{\mathrm{a}}$ & $48.6^{a}$ & $48.6^{a}$ \\
\hline Average & 52.1 & 48.7 & 50.4 & 48.6 & 48.6 \\
\hline LSD (0.05) & 1.9 & 3.1 & 6.1 & 4.7 & 4.7 \\
\hline CV (\%) & 6.7 & 7.6 & 12.3 & 10.1 & 10.1 \\
\hline $\mathrm{R}^{2}$ & 0.6 & 0.6 & 0.6 & 0.6 & 0.6 \\
\hline \multicolumn{6}{|l|}{ Subplot } \\
\hline Spray & $53.1^{\mathrm{a}}$ & $49.2^{a}$ & $51.2^{\mathrm{a}}$ & $50.1^{\mathrm{a}}$ & $49.4^{a}$ \\
\hline Soil & $51.2^{\mathrm{a}}$ & $49.0^{\mathrm{a}}$ & $49.5^{a}$ & $48.6^{b}$ & $47.9^{b}$ \\
\hline LSD (0.05) & 1.3 & 1.9 & 1.9 & 1.3 & 1.3 \\
\hline \multicolumn{6}{|l|}{ Sub subplot } \\
\hline Dose $50 \%$ & $51.6^{b}$ & $49.0^{\mathrm{a}}$ & $50.4^{a}$ & $49.3^{a}$ & $48.6^{a}$ \\
\hline Dose $100 \%$ & $53.4^{\mathrm{a}}$ & $48.5^{a}$ & $50.6^{a}$ & $49.7^{a}$ & $48.9^{a}$ \\
\hline Dose $200 \%$ & $51.5^{b}$ & $49.7^{a}$ & $50.1^{\mathrm{a}}$ & $49.1^{\mathrm{a}}$ & $48.4^{a}$ \\
\hline LSD (0.05) & 1.5 & 1.6 & 2.7 & 2.1 & 2.1 \\
\hline
\end{tabular}

$\S$ Values followed by the same letter within the same column do not differ statistically from each other (Tukey $\leq 0.05$ ) due to damages caused by diseases, insects or frost. In the present work, plants showed little variation in chlorophyll content throughout the crop cycle, with a maximum value of 53.09 and a minimum of 47.32 SPAD units, without reaching the critical value (Table 6). According to Rincón and Ligarreto (2010), for having a desirable grain yield in the maize crop plants must have 50 SPAD units or higher, and the critical minimal value is $35.3 \mathrm{SPAD}$ units, equivalent to $1.83 \%$ nitrogen in the plant.

\section{Healthy and rotten ears}

The number of healthy ears did not show significant differences between treatments. However, the Consist Max ${ }^{\circledR}$ treatment had a lower percent of rotten ears (Table 7).

\section{Grain yield (t ha-1)}

Significant differences between treatments were registered $(\alpha=0.05)$ in grain yield adjusted to $15 \%$ moisture, where Consist Max ${ }^{\circledR}$ yielded $13.40 \mathrm{t} \mathrm{ha}^{-1}$, followed by Serenade $\operatorname{Max}^{\circledR}$ with $12.67 \mathrm{t} \mathrm{ha}^{-1}$ (Table 7). There were no significant differences among the application methods. But the plant response nts to the doses had significant effect $(\alpha=0.05)$, since yield increased when the product was applied at twice the recommended dose, resulting in a significant gain in grain yield (Table 7).

Commercially, Consist Max ${ }^{\circledR}$ is a fungicide with tebuconazole (triazole) and trifloxystrobin as active ingredients. This

Table 7: Effect of treatments on the number of healthy and per cent of rotten ears, and grain yield in maize. Average values calculated from two growing seasons ${ }^{\S}$

\begin{tabular}{|c|c|c|c|}
\hline & $\begin{array}{c}\text { No. healthy } \\
\text { ears* }\end{array}$ & $\begin{array}{c}\text { Rotten } \\
\text { ears (\%)* }\end{array}$ & $\begin{array}{l}\text { Grain yld } \\
\text { (t ha-1)* }\end{array}$ \\
\hline \multicolumn{4}{|l|}{ Main plot } \\
\hline Consist Max ${ }^{\circledR}$ & $29.9^{a}$ & $2.6^{a}$ & $13.4^{a}$ \\
\hline Serenade Max ${ }^{\circledR}$ & $29.3^{a}$ & $4.4^{\mathrm{abc}}$ & $12.7^{b}$ \\
\hline Actigard $^{\circledR}$ & $29.3^{a}$ & $5.8^{c}$ & $12.3^{\mathrm{ab}}$ \\
\hline Alliete $^{\circledR}$ & $29.4^{a}$ & $3.4^{\mathrm{ab}}$ & $12.5^{\mathrm{ab}}$ \\
\hline Poncho Votivo ${ }^{\circledR}$ & $28.8^{a}$ & $3.3^{a b}$ & $12.4^{\mathrm{ab}}$ \\
\hline Messenger ${ }^{\circledR}$ & $26.9^{a}$ & $2.7^{\mathrm{a}}$ & $12.3^{\mathrm{ab}}$ \\
\hline Control & $28.2^{\mathrm{a}}$ & $5.3^{\mathrm{ab}}$ & $12.6^{\mathrm{ab}}$ \\
\hline Average & 28.8 & 3.9 & 12.6 \\
\hline LSD (0.05) & 3.3 & 0.6 & 1.4 \\
\hline CV $(\%)$ & 8.4 & 3.8 & 5.8 \\
\hline $\mathrm{R}^{2}$ & 0.7 & 0.6 & 0.8 \\
\hline \multicolumn{4}{|l|}{ Subplot } \\
\hline Application spray & $28.7^{a}$ & $1.2^{\mathrm{a}}$ & $12.7^{a}$ \\
\hline Application soil & $28.9^{b}$ & $1.1^{\mathrm{a}}$ & $12.5^{a}$ \\
\hline LSD (0.05) & 1.6 & 0.4 & 0.6 \\
\hline \multicolumn{4}{|l|}{ Sub subplot } \\
\hline Dose $50 \%$ & $29.2^{\mathrm{a}}$ & $1.2^{\mathrm{a}}$ & $12.5^{b}$ \\
\hline Dose $100 \%$ & $28.6^{a}$ & $1.0^{\mathrm{a}}$ & $12.5^{\mathrm{ab}}$ \\
\hline Dose $200 \%$ & $28.7^{\mathrm{a}}$ & $1.3^{\mathrm{a}}$ & $12.8^{a}$ \\
\hline LSD (0.05) & 1.1 & 0.4 & 0.32 \\
\hline
\end{tabular}

§Values followed by the same letter within the same column, do not differ statistically from each other (Tukey $<0.05$ ). 
compound belongs to the group of strobilurins, which decrease the severity of P. sorghi and significantly increase the maize grain yield (Carmona et al., 2009; Nelson et al., 2015). According to Lazo and Ascencio (2014), in addition to a fungicide action, the strobilurins have a positive influence on the metabolic and physiologic processes, by altering the phytohormone levels, delaying senescence processes and increasing grain yield. In their research in with maize, these researchers also reported an increase in the photosynthetic rate, chlorophyll content, biomass production and leaf size (length and width).

In other investigations, with the application of strobilurines and enough nitrogen, the flag leaf showed an increase in longevity, accumulating higher amounts of chlorophyll by improving the nitrate assimilation, increasing the biomass allocated in the grains and consequently increasing grain yield (Kanungo and Joshi, 2014). According to our results, it is postulated that Consist Max ${ }^{\circledR}$ can stimulate physiological pathways of the host resulting in the improvement of flowering interval, ear aspect, photosynthetic rate, number of healthy ears, lesser percentage of rotten ears, and lower severity of the pathogen, as well as a $6.2 \%$ gain in grain yield as compared to the control. According to Acuña and Grabowski (2012), a resistance inducer has a triple function: activates the defenses in plants, exerts antimicrobial action and promotes plant growth. Considering their mode of action, these products constitute a new class of pesticides called "fourth generation fungicides".

Treatments with Serenade $\operatorname{Max}^{\circledR}$ (Bacillus subtilis) stimulated the growth of maize plants but without improving the grain yield compared to the control (Table 7). Vega et al. (2016) indicate that bacteria of the genus Bacillus sp. are capable of producing auxins which act as hormones involved in physiological processes thus increasing the biomass accumulation and grain yield, as well as participating in defensive mechanisms against biotic and abiotic stresses. The rest of the inducers, including Poncho Votivo $^{\circledR}$, Alliete $^{\circledR}$, Messenger ${ }^{\circledR}$ and Actigard 50 GS $^{\circledR}$, also managed to reduce the severity of $P$. sorghi but without gains in grain yield since their values were similar to the control (Table 7).

These results suggest that an application of these products is not enough to efficiently stimulate the physiological pathways involved in increasing grain yield. It is necessary to continue these investigations to determine the route of energy concentration, evaluate more applications, and determine if the efficiency of these products is conditioned by environmental factors. Gómez and Reis (2011) mention that, depending on the inducer and the crop, its action can be activated at the moment of application or it can be extended up to 30 days, or more.

\section{CONCLUSIONS}

Due to its mode of action, Consist Max ${ }^{\circledR}$ (tebuconazole + trifloxystrobin) can be considered "fourth generation fungicide" due to its ability to inhibit the growth of the pathogen and, simultaneously stimulate the physiological pathways of the host, to become the best treatment in improving flowering interval, ear aspect, net rate of photosynthesis, lower the percent of rotten ears, and reducing severity of damage caused by $P$. sorghi. In consequence, it caused an increase in grain yield of 6.2 $\%$ over the control. The best method of application is spray, which in spite of not having significant differences in yield, it improved the concentration of chlorophyll and achieved the greatest decrease in the severity of P. sorghi. The best dose was twice the commercially recommended (200\%), showing the most significant influence on grain yield.

\section{Author's contributions}

Carmen Alicia Zúñiga-Silvestre conducted the field experiments, collected the data, performed the statistical analyses, and wrote her MSc dissertation based on this project. Carlos De-León-García-de-Alba directed and sponsored the project, and wrote this manuscript. Victoria Ayala-Escobar collaborated in the project as adviser on plant pathogens. Víctor A. González-Hernández collaborated in the project execution as plant physiologist, and revised the manuscript.

\section{REFERENCES}

Acuña, G. E. M. and O. C. Grabowski. 2012. Inducción de resistencia en plantas de trigo (Triticum aestivum L.) a la mancha amarilla (Drechslera tritici-repentis) y marrón (Bipolaris sorokiniana). Invest. Agrar. 14(2): 71-79.

Angeles, G. E., T. E. Ortiz, P. A. López and R. G. López. 2010. Caracterización y rendimiento de poblaciones de maíz nativas de Molcaxac, Puebla. Rev. Fitotecnia Mex. 33(4): 287-296.

Edmeades, G. O., J. Bolanos, A. Elings, J. M. Ribaut and M. E. Westgate. 1996. The role and regulation of the anthesissilking interval in maize. Physiology and modeling kernel set in maize. Field Crops Res. 48: 65-80.

Carmona, M., F. Sautua, M. Quiroga, C. Díaz and P. Fernández. 2009. Control químico de la roya común del maíz (Puccinia sorghi): Criterio basado en el umbral de daño económico (UDE). Trop. Plant Pathol. 34: S120.

García, E. 1988. Modificaciones al Sistema de Clasificación Climática de Köppen. Serie Libros 6. Universidad Nacional Autónoma de México, Instituto de Geografía,, pp. 7-91.

Gómez, D. E. and E. M. Reis. 2011. Inductores abióticos de resistencia contra fitopatógenos. Rev. QuímicaViva. 1(10): 6-17.

González, M. 2005. Roya Común del Maíz: Altos Niveles de Severidad en la Zona Maicera Núcleo (Campaña 04/05). [Common Rust of Maize: High Levels of Severity in the Core Maize Area (Growing Season 04/05)]. Agromensajes 15.

González, V. D. M., L. J. Goicochea, M. A. A. Quintero, G. J. L. Rubio 
and M. J. A. Aranguren. 2007. Análisis de tres procedimientos estadísticos para la evaluación del crecimiento de mautas mestizas bajo diferentes regímenes nutricionales. Rev. Cient. Vet. 17(2): 136-142.

Grande, T. C. D. and C. B. S. Orozco. 2013. Producción y procesamiento del maíz en Colombia. Rev. Guillermo de Ockham. 11(1): 97-110.

Gutiérrez, R. M., R. M. Paul, E. J. A. Escalante and S. A. Larqué. 2005. Algunas consideraciones en la relación entre fotosíntesis y el rendimiento de grano en trigo. Cienc. Ergo Sum. 12(2): 149-154.

Hanway, J. J. 1966. How a corn plant develops. Special Report No. 38. lowa Agricultural and Home Economics. Experiment Station Publications. Iowa State University of Science and Technology. Cooperative Extension Service, Ames, lowa, p. 37.

Hongguang, C., C. Qun, G. Riliang, Y. Lixing, L. Jianchao, Z. Xiuzhi, C. G. Fanjun and M. Z. Fusuo. 2012. Identification of QTLs for plant height, ear height and grain yield in maize (Zea mays L.) in response to nitrogen and phosphorus supply. Plant Breed. 131: $502-510$.

IBPGR. 1991. Descriptors for Maize. International Maize and Wheat Improvement Center, Mexico City/International Board for Plant Genetic Resources, Rome, p. 85.

INIFAP (Instituto Nacional de Investigaciones Forestales, Agrícolas y Pecuarias). 2015. El Tratamiento de Semilla Para la Siembra de Maíz en P-V, México. Available from: http://www.scielo.org.mx/ scielo.php?script=sci_arttext\&pid=S2007-09342014000500012. [Last accessed on 2017 Jun 12].

Jiménez, M. A., A. Asdrubal, D. Ulacio and A. Herández. 2012. Evaluación de Trichoderma spp. y Acibenzolar-S-Metil (Bion®) como inductores de resistencia a la pudrición blanca Sclerotium cepivorum Berk. En ajo (Allium sativum L.) bajo condiciones de campo. J. Selva Andina Res. Soc. 1(1): 14-25.

Kanungo, M. and J. Joshi. 2014. Impact of pyraclostrobin (F-500) on crop plants. Plant Sci. Today. 1(3): 174-178.

Lazo, J. V. and J. Ascencio. 2014. Algunas respuestas morfométricas y fisiológicas inducidas por el fungicida Opera ${ }^{\circledR}$ (Pyraclostrobin + Epoxiconazole) en la planta de maíz (Zea mays L.). Rev. Fac. Agron. (LUZ). 31: 39-59.

MacRobert, J. F., P. S. Setimela, J. Gethi and M. Worku. 2015. Manual de Producción de Semilla de Maíz Híbrido. México, D.F. Centro Internacional de Mejoramiento de Maíz y Trigo (CIMMYT). El Batán, México, p. 26.

Mendoza, E. M., V. C. Mosqueda, L. J. A. Rangel, B. A. López, H. S. A. Rodríguez, M. L. Latournerie and M. E. Moreno. 2006.
Densidad de población y fertilización nitrogenada en la clorofila, materia seca y rendimiento de maíz normal y QPM. Agric. Técnica México. 32(1): 89-99.

Nelson, K. A., C. J. Dudenhoeffer, B. Burdick and D. Harder. 2015. Enhanced efficiency foliar nitrogen and pyraclostrobin applications for high yielding corn. J. Agric. Sci. 7(10): 17-28.

Noriega, G. L. A., O. R. E. Preciado, E. E. Andrino, I. A. D. Terrón and P. J. Covarrubia. 2011. Fenología, crecimiento y sincronía floral de los progenitores del híbrido de maíz QPM H-374C. Rev. Mex. Cienc. Agríc. 2(4): 489-500.

Palafox, C. A., M. F. Rodríguez, M. M. Sierra, P. A. Meza and S. L. Tehuacatl. 2016. Comportamiento agronómico de híbridos de maíz formados con líneas tropicales sobresalientes. Química, Biología y Agronomía. Handbook T-I.๑ Ecorfan. 1: 52-62.

Programa de Maíz, Centro Internacional de Mejoramiento del Maíz y Trigo (CIMMYT). 2004. Enfermedades del Maíz: Una Guía Para su Identificación en el Campo. $4^{\text {th }}$ ed. Centro Internacional de Mejoramiento del Maíz y Trigo (CIMMYT), México, D.F, p. 118.

Reynoso, Q. C. A., H. A. González, L. D. J. Pérez, M. O. Franco, F. J. L. Torres, C. G. A. Velázquez, L. C. Breton, M. A. Balbuena and V. O. Mercado. 2014. Análisis de 17 híbridos de maíz sembrados en 17 ambientes de los Valles Altos del centro de México. Rev. Mex. Cienc. Agríc. 55(5): 871-882.

Rincón, C. A. and G. A. Ligarreto. 2010. Relación entre nitrógeno foliar y el contenido de clorofila, en maíz asociado con pastos en el Piedemonte Llanero colombiano. Cienc. Tecnol. Agropecu. 11(2): 122-128.

Ritchie, S. W., J. J. Hanway and G. O. Benson. 1986. How a Corn Plant Develops. lowa State University of Science and Technology. Cooperative Extension Service, Ames, lowa, p. 21.

Rodríguez, M. E., R. M. V. Micca, N. R. Andrada and A. S. Larrusse. 2015. Parametrización epidémica para evaluar sistemas de manejo de roya común (Puccinia sorghi), en San Luis. FAVE Secc. Cienc Agrar. 14(2): 1-10.

Sandoval, R. F. S., A. J. G. Arreola, M. A. Lagarda, C. R. Trejo, A. O. Esquivel and H. G. García. 2010. Efecto de niveles de $\mathrm{NaCl}$ sobre fotosíntesis y conductancia estomática en nogal pecanero (Carya illinoinensis (Wangeh.) K. Koch). Rev. Chapingo Ser. Zonas Áridas. 9: 135-141.

Shah, D. A. and H. R. Dillard. 2010. Managing foliar diseases of processing sweet corn in New York with strobilurin fungicides. Plant Dis. 94(2): 213-220.

Vega, C. P., M. H. Canchignia, M. González and M. Seeger. 2016. Biosíntesis de ácido indol-3-acético y promoción del crecimiento de plantas por bacterias. Cult. Trop. 37 (Supll 1): 33-39. 